\title{
KARAKTERISTIK FUNGSIONAL PROTEIN MISELIUM JAMUR TIRAM MERAH MUDA DAN MERANG
}

\author{
[Functional Characteristics of Protein Mycelium of Pink Oyster and Paddy Straw Mushrooms] \\ Sukarno ${ }^{1)^{*}}$, Nadia T. Hendartina1), Dedi Fardiaz ${ }^{1)}$ dan Nampiah Sukarno²) \\ 1) Departemen IImu dan Teknologi Pangan, Fakultas Teknologi Pertanian, Institut Pertanian Bogor, Bogor \\ 2) Departemen Biologi, Fakultas Matematika dan IImu Pengetahuan Alam, Institut Pertanian Bogor, Bogor
}

Diterima 12 Maret 2014 / Disetujui 13 Juni 2014

\begin{abstract}
Mycelium of mushroom contained high protein, which determined its functional characteristics such as water holding capacity (WHC), oil holding capacity (OAC), emulsion stability, and gel formation. This study aimed to determine the protein functional properties of Pleurotus flabellatus and Volvariella volvacea mycelia. Information obtained can be used to increase utilization of the mycelia as source of food. Mycelia biomass were obtained by growing the fungal cultures in Potato Dextrose Broth (PDB) on shaker at 100-150 rpm. Mycelia were harvested three times at 7, 8, and 9-days after inoculation for measuring their protein contents by kjehdahl method. Functional properties of mycelium protein measured were WHC, OAC, emulsion stability, and gel formation by folding test method. Based on the analysis of protein content in dry weight basis, 8-day old P. flabellatus and V. volvacea mycelia produced the highest protein contents with the value were 31.72 and $19.98 \%$, respectively. Further analysis of protein functional properties showed that $P$. flabellatus mycelium had $10.38 \%$ of WHC, $0.52 \mathrm{~mL} / \mathrm{g}$ of OAC, $57.14 \%$ of emulsion stability and gel strength level with the value of 2, whereas the V. volvacea mycelium had $15.89 \%$ of WHC, $0.80 \mathrm{~mL} / \mathrm{g}$ of OAC, $48.69 \%$ of emulsion stability, and did not form a gel. Protein functional properties of $P$. flabellatus were better than that of $V$. volvacea mycelium in terms of protein content, emulsion stability, and gel formation.
\end{abstract}

Keyword: mycelium, Pleurotus flabellatus, protein functional properties, Volvariella volvacea

\begin{abstract}
ABSTRAK
Miselium memiliki kandungan protein cukup tinggi yang dapat mempengaruhi karakteristik fungsional proteinnya seperti daya ikat air, daya serap minyak, stabilitas emulsi, dan pembentukan gel. Penelitian ini bertujuan untuk memperoleh informasi mengenai karakteristik fungsional protein miselium Pleurotus flabellatus dan Volvariella volvacea sehingga dapat meningkatkan pemanfaatannya dalam bidang pangan. Biomassa miselium diperoleh dengan menumbuhkan kultur jamur pada media Potato Dextrose Broth (PDB) yang diletakkan pada mesin penggoyang dengan kecepatan 100-150 rpm. Pemanenan miselium dilakukan sebanyak tiga kali yaitu pada hari ke-7, 8, dan 9 setelah inokulasi untuk analisis kandungan protein dengan metode kjehdahl. Analisis sifat fungsional protein lainnya yang dilakukan ialah pengukuran daya ikat air, daya serap minyak, stabilitas emulsi, dan pembentukan gel dengan folding test. Berdasarkan hasil analisis kandungan protein, miselium $P$. flabellatus dan $V$. volvacea pada umur delapan hari setelah inokulasi memiliki kandungan protein tertinggi yaitu secara berturut-turut 31.72 dan $19.98 \%$ (bk). Hasil analisis lebih lanjut terhadap karakteristik fungsional protein menunjukkan bahwa protein miselium $P$. flabellatus memiliki nilai daya ikat air $10.38 \%$, daya serap minyak $0.52 \mathrm{~mL} / \mathrm{g}$, stabilitas emulsi $57.14 \%$, dan kekuatan gel sebesar 2, sedangkan protein miselium $V$. volvacea mempunyai nilai daya ikat air $15.89 \%$, daya serap minyak sekitar $0.80 \mathrm{~mL} / \mathrm{g}$, stabilitas emulsi $48.69 \%$, dan tidak dapat membentuk gel. Karakterisitik fungsional protein miselium $P$. flabellatus lebih baik dibandingkan dengan $V$. volvacea ditinjau dari kandungan protein, stabilitas emulsi, dan kemampuan pembentukan gelnya.
\end{abstract}

Kata kunci: miselium, Pleurotus flabellatus, sifat fungsional protein, Volvariella volvacea

\section{PENDAHULUAN}

Protein merupakan salah satu komponen zat gizi yang penting dalam bahan dan produk pangan. Jamur merupakan bahan pangan nabati yang mengandung protein cukup tinggi. Chang dan Miles (2004) menyebutkan secara umum jamur mengandung sekitar 19-35\% protein (bk). Jamur juga mengandung semua asam amino esensial bagi manusia, termasuk asam amino yang mengandung gugus sulfur. Asam amino yang memiliki gugus sulfur ini dapat menjadi prekursor pada reaksi maillard untuk membentuk aroma daging selama

*Penulis Korespondensi:

E-mail: dsukarno@ipb.ac.id; dsukarno@gmail.com pengolahan dengan pemanasan (Wong et al. 2008). Jamur juga dapat dijadikan sumber serat pangan dan memiliki kandungan asam lemak tidak jenuh seperti asam linoleat. Hung dan Nhi (2012) menyebutkan saat ini jamur telah popular sebagai bahan pangan karena memiliki kandungan zat gizi yang baik sehingga dapat dijadikan sebagai pangan fungsional. Penelitian yang dilakukan oleh Richi (2011) menyebutkan bahwa jamur pangan ektomikoriza bolet yang tumbuh di Indonesia dan dikonsumsi di daerah Bangka Belitung memiliki kandungan protein sekitar $15.47 \%$, karbohidrat $75.81 \%$, serta merupakan sumber serat yang baik karena mengandung serat pangan sekitar $11.71 \%$. Jamur ini juga mengandung komponen total fenolik $4.77 \mathrm{mg}$ AGE/g, beta karoten, dan likopen sehingga potensial dijadikan sumber antioksidan. 
Jenis jamur konsumsi yang telah dikenal dan dijual secara komersial di antaranya adalah jamur kuping (Herniola sp.), jamur tiram (Pleurotus ostreatus), jamur merang (Volvariella volvacea), dan jamur shiitake (Lentinula edodes) (Hung dan Nhi, 2012). Dalam pertumbuhannya, jamur mengalami dua tahapan yaitu pertumbuhan struktur somatik berupa miselium dan struktur reproduktif yaitu tubuh buah. Miselium merupakan kumpulan hifa yang saling berhubungan dan membentuk struktur seperti serabut. Miselium juga memiliki kandungan protein. Nilai kandungan protein miselium dapat dipengaruhi di antaranya oleh komposisi media pertumbuhannya (Hosseini dan Darani, 2010; Mshandete dan Mgonja, 2009).

Protein dalam sistem pangan dapat memberikan pengaruh yang signifikan terhadap karakteristik dan atribut sensori pangan (Adebowale dan Lawal, 2004). Karakteristik fungsional protein sangat penting dalam proses dan formulasi produk pangan. Beberapa karakteristik fungsional protein yang penting yaitu daya ikat air dan minyak, emulsifikasi, kapasitas pembentukan buih, dan kemampuan pembentukan gel (Asgar et al. 2010; Wu et al. 2009). Informasi mengenai sifat fungsional protein diperlukan untuk memaksimalkan pemanfaatan bahan baku dalam produk pangan. Kemampuan mengikat air dan minyak dapat dimanfaatkan dalam pengembangan produk daging (Deng et al. 2011). Kemampuan pembentukan emulsi dan stabilitas emulsi diperlukan pada produk salad, sosis, dan sup (Nassar, 2008). Kapasitas pembentukan buih diperlukan dalam menjaga tekstur dan struktur produk es krim dan roti selama dan setelah proses (Adebayo et al. 2013). Kemampuan pembentukan gel diperlukan dalam produk pangan seperti produk confectionery (Fekria et al. 2012).

Hipotesis dalam penelitian ini ialah adanya kandungan protein pada miselium jamur tiram merah muda (Pleurotus flabellatus) dan merang (Volvariella volvacea) dapat memberikan karakteristik fungsional meliputi daya ikat air, daya serap minyak, stabilitas emulsi, dan pembentukan gel. Hasil yang diharapkan ialah adanya perbedaan karakteristik fungsional protein dari kedua miselium jamur yang digunakan karena perbedaan kandungan protein dan spesiesnya sehingga penelitian ini dapat menghasilkan informasi yang dapat digunakan untuk peningkatan pemanfaatan dari masing-masing miselium tersebut dalam bidang pangan. Penelitian ini bertujuan untuk mengetahui karakteristik fungsional protein pada miselium $P$. flabellatus dan $V$. volvacea pada hari pemanenan dengan kandungan protein optimal meliputi daya ikat air, daya serap minyak, stabilitas emulsi, dan kekuatan gel.

\section{BAHAN DAN METODE}

Kultur produksi miselium $P$. flabellatus dan V. volvacea

Kultur induk $P$. flabellatus dan $V$. volvacea diperoleh dari IPBCC, FMIPA, IPB, Bogor.

\section{Produksi miselium $P$. flabellatus dan $V$. volvacea}

Kultur induk diremajakan pada media PDA (Potato Dextrose Agar, Oxoid, England) dan diinkubasi selama 8 hari (Lakshmi, 2013; Mshandete dan Mgonja, 2009). Biomassa miselium dari kedua jamur diperoleh dengan menumbuhkan kultur hasil peremajaan ke dalam media cair (Potato Dextrose Broth, Difco $^{\mathrm{TM}}, \mathrm{USA}$ ) yang ditempatkan dalam erlenmeyer. Inkubasi dalam media PDB dilakukan meng-gunakan shaker dengan kecepatan 100-150 rpm dan suhu $28-30^{\circ} \mathrm{C}$ (suhu ruang) (Aminuddin et al. 2007; Mshandete dan Mgonja, 2009). Sebelum pemanenan biomassa, suhu inkubasi dinaikkan hingga $68^{\circ} \mathrm{C}$ selama 30 menit untuk menurunkan kadar asam nukleat yang terkandung dalam miselium. Pemanenan miselium untuk analisis kandungan protein dilakukan sebanyak tiga kali yaitu hari ke-7, 8, dan 9 setelah inokulasi.

\section{Analisis kandungan protein}

Miselium $P$. flabellatus dan $V$. volvacea masing-masing dihaluskan secara terpisah. Sejumlah 1-2 g masing-masing miselium yang diperoleh dari tiga kali pemanenan ditimbang untuk dianalisis kandungan proteinnya. Kandungan protein miselium dianalisis dengan mengukur kandungan total nitrogen menggunakan metode kjehdahl (AOAC, 1995). Faktor konversi total nitrogen menjadi kandungan protein untuk sampel miselium yang digunakan dalam perhitungan adalah 4.38 (Kalac, 2012; Reis et al. 2012). Selain itu, sejumlah 1-2 g sampel miselium dianalisis kadar airnya. Analisis kadar air dilakukan dengan metode gravimetri (AOAC, 1995) yang bertujuan untuk memperoleh kandungan protein bahan kering.

\section{Analisis daya ikat air/Water Holding Capacity (WHC)}

Water holding capacity (WHC) diukur dengan menggunakan metode Wroldstad et al. (2005). Sebanyak 1-2 g sampel yang telah dihaluskan ditimbang dan ditempatkan dalam kertas saring Whatman no. 1 sebanyak 3 lembar. Kemudian, sampel disentrifugasi (Hermle Z 383K, Germany) dengan kecepatan $1118 \mathrm{xg}$ selama 15 menit pada suhu ruang. Setelah itu, sampel dipisahkan dari kertas saring dan ditimbang. Nilai WHC dihitung menggunakan rumus:

$$
\% \mathrm{WHC}=\frac{\text { berat sampel }(\mathrm{g}) \text { setelah disentrifus }}{\text { berat sampel }(\mathrm{g}) \text { sebelum disentifus }} \times 100
$$

\section{Analisis daya serap minyak/Oil Absorption Capacity (OAC)}

Pengukuran nilai OAC dilakukan dengan metode Lin et al. (1974). Campuran $0.5 \mathrm{~g}$ sampel dengan $3 \mathrm{~mL}$ minyak jagung dimasukkan ke dalam tabung sentrifus berukuran $25 \mathrm{~mL}$ dan divortex selama 2 menit. Tabung sentrifus dimasukkan dalam penangas bersuhu $25^{\circ} \mathrm{C}$ selama 30 menit, dilanjutkan dengan sentrifugasi (Hermle Z383K, Germany) pada $402 \mathrm{xg}$ selama 10 menit. Volume minyak terikat diperoleh dengan cara mengurangi volume awal minyak yang ditambahkan dengan volume minyak bebas. Nilai OAC dihitung menggunakan rumus:

$$
\mathrm{OAC}(\mathrm{mL} \text { minyak } / \mathrm{g})=\frac{\mathrm{mL} \text { minyak terikat }}{\text { berat sampel }(\mathrm{g})}
$$

\section{Analisis stabilitas emulsi/emulsion stability}

Stabilitas emulsi diukur dengan menggunakan metode yang dijabarkan oleh Xie dan Hettiarachchy (1997). Campuran yang terdiri dari $2 \mathrm{~mL}$ minyak jagung murni dan $6 \mathrm{~mL} 0.1 \%(\mathrm{~b} / \mathrm{v})$ larutan sampel dihomogenizer (Silverson L4R, USA) pada skala 
6 selama 1 menit. Sebanyak $50 \mu \mathrm{L}$ emulsi yang terbentuk diambil dari dasar wadah pada 0 dan 10 menit dan dicampur dengan $5 \mathrm{~mL} 0.1 \%$ SDS. Absorbansi dari emulsi diukur pada $500 \mathrm{~nm}$ dengan spektofotometer UV-Vis (Shimadzu, Kyoto Japan). Turbidity (Absorbansi) pada waktu 0 menit diberi lambang To dan 10 menit diberi lambang T. Stabilitas emulsi ditentukan dengan perumusan dan dinyatakan sebagai (\%) dan dihitung dengan menggunakan rumus:

$$
\text { Stabilitas emulsi }(E S)=\frac{T}{T 0}
$$

\section{Penentuan kekuatan gel}

Kekuatan gel diukur dengan menggunakan metode folding test menurut Suzuki (1981). Sebanyak $300 \mathrm{~g}$ sampel ditambahkan $3 \% \mathrm{NaCl}$, kemudian diaduk, lalu dicetak membentuk irisan 4-5 mm. Setelah itu, sampel dipanaskan pada suhu $40^{\circ} \mathrm{C}$ selama 30 menit, lalu dilanjutkan pada suhu $90^{\circ} \mathrm{C}$ selama 30 menit. Sampel lalu ditekan antara ibu jari dan telunjuk. Kekuatan gel diukur secara kualitatif dengan memberikan nilai sesuai dengan kelompok mutu gel. Pengelompokkan mutu untuk pengukuran gel adalah:

1 : patah saat ditekan dengan jari (D)

2 : retak merata saat pelipatan pertama $(C)$

3 : retak tidak merata saat pelipatan pertama $(B)$

4 : tidak retak setelah $1 \times$ pelipatan $(A)$

5 : tidak retak setelah $2 \times$ pelipatan $(A A)$

\section{Analisis statistika}

Data ditampilkan sebagai nilai rata-rata \pm standar deviasi. Data dianalisis menggunakan uji ragam atau Analysis of Variance (ANOVA) dan taraf signifikansi 0.05. Uji lanjut yang digunakan adalah uji Duncan. Pengolahan data menggunakan program SPSS versi 16.0 (Chicago, USA).

\section{HASIL DAN PEMBAHASAN}

\section{Kandungan protein miselium $P$. flabellatus dan $V$. volvacea}

Data hasil analisis kandungan protein miselium $P$. flabellatus memperlihatkan terjadinya peningkatan nilai protein sampai hari panen ke-8, kemudian menurun pada hari ke- 9 . Namun demikian, nilai protein pada hari panen ke-9 lebih tinggi dibandingkan dengan hari ke-7 (Gambar 1). Pola yang hampir sama terjadi pada miselium $V$. volvacea. Namun, pada miselium $V$. volvacea nilai kandungan protein pada hari panen ke-9 lebih rendah daripada hari ke-7 (Gambar 1). Miselium P. flabellatus dan $V$. volvacea memiliki kandungan protein (bk) tertinggi pada hari panen yang sama yaitu hari ke-8, dengan nilai secara berurutan adalah 31.72 dan $19.98 \%$. Kandungan protein miselium $P$. flabellatus pada ketiga hari pemanenan cenderung lebih tinggi daripada miselium V. volvacea.

Perubahan nilai kandungan protein pada kedua miselium dapat dijelaskan melalui pola pertumbuhan yang terjadi. Chang dan Miles (2004) menyebutkan peningkatan biomassa dapat menjadi salah satu kriteria terjadinya pertumbuhan. Pertumbuhan kedua miselium memperlihatkan pola yang sama sampai hari ke-8. Namun, pola menuju panen hari ke-9 berbeda (Gambar 2).

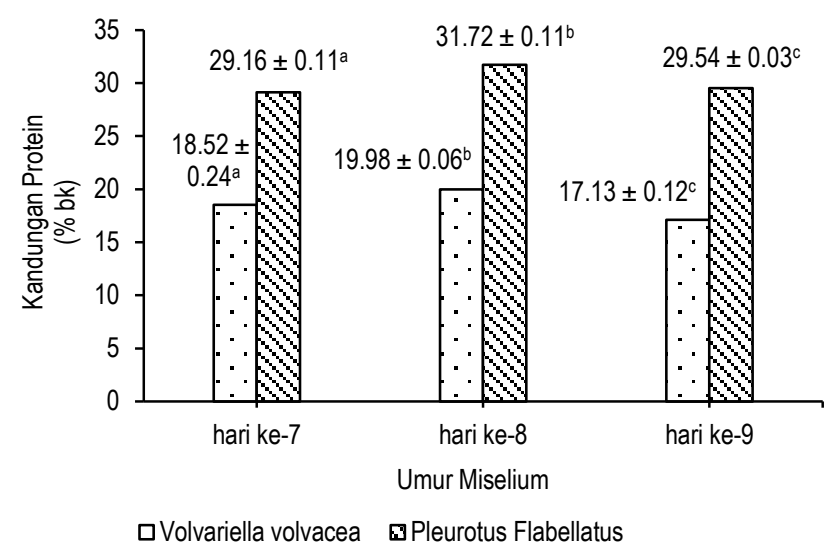

Gambar 1. Kandungan protein miselium Pleurotus flabellatus dan Volvariella volvacea pada umur pemanenan yang berbeda. Data dengan huruf yang berbeda menandakan terjadi perbedaan yang signifikan pada taraf signifikansi 0.05

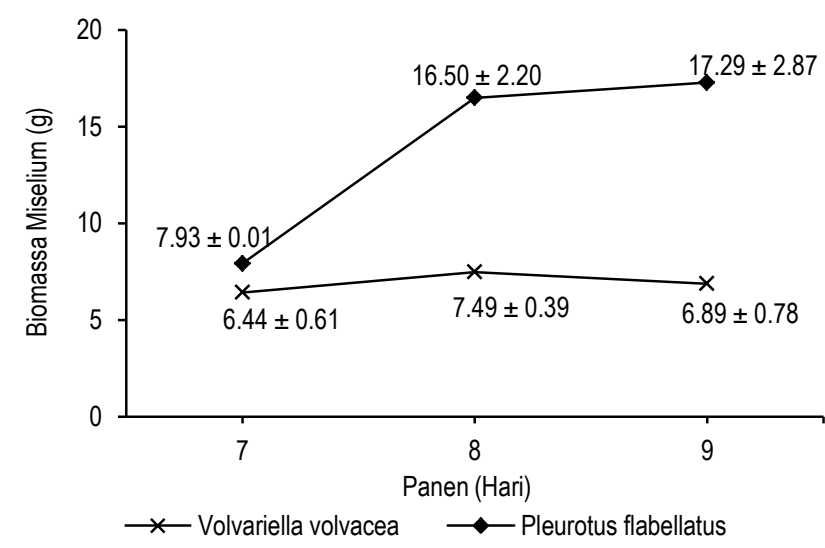

Gambar 2. Biomassa yang diperoleh pada ketiga hari pemanenan miselium

Miselium $P$. flabellatus pada hari ke-9 mengalami peningkatkan biomassa dengan laju pertumbuhan lebih lambat daripada laju pertumbuhan sampai hari ke-8, sedangkan miselium $V$. volvacea mengalami penurunan biomassa pada hari ke-9. Berdasarkan data hasil pengukuran biomassa pada Gambar 2, terlihat bahwa kedua miselium pada hari ke-8 terdapat dalam fase logaritmik. Chang dan Miles (2004) menyebutkan dalam fase logaritmik dihasilkan metabolit primer yang dibutuhkan untuk pertumbuhan. Miselium kedua spesies jamur pada hari ke-8 memiliki kandungan protein yang optimal karena terjadinya sintesis protein sebagai metabolit primer. Hasil ini didukung oleh Srivastava dan Bano (1970) yang menyebutkan bahwa secara umum miselium $P$. flabellatus mengalami pertumbuhan maksimal pada umur 8 hari setelah inokulasi karena miselium tersebut telah memanfaatkan substratnya secara maksimal. Perbedaan pola kandungan protein pada hari panen ke-9 di antara kedua spesies miselium dapat disebabkan oleh perbedaan pola pertumbuhan pada hari ke-9. Pada hari ke-9 miselium $V$. volvacea telah memasuki fase penurunan pertumbuhan. Penurunan pertumbuhan dapat terjadi akibat adanya autolisis karena toksin hasil metabolit meningkat atau kandungan zat gizi dalam media yang berkurang (Chang dan Miles, 2004). 


\section{Daya ikat air/Water Holding Capacity (WHC)}

Nilai WHC V. volvacea lebih tinggi daripada miselium $P$. flabellatus dengan nilai secara berturut-turut ialah 15.89 dan $10.38 \%$ (Tabel 1).

Tabel 1. Sifat fungsional protein miselium Pleurotus flabellatus dan Volvariella volvacea

\begin{tabular}{lcc}
\hline \multirow{2}{*}{ Parameter } & \multicolumn{2}{c}{ Miselium } \\
\cline { 2 - 3 } & Pleurotus flabellatus & Volvariella volvacea \\
\hline Daya ikat air (\%) & $10.38 \pm 0.20^{\mathrm{b}}$ & $15.89 \pm 0.84^{\mathrm{a}}$ \\
Daya serap minyak (mL/g) & $0.52 \pm 0.02^{\mathrm{b}}$ & $0.80 \pm 0.07^{\mathrm{a}}$ \\
Stabilitas emulsi (\%) & $57.14 \pm 1.84^{\mathrm{a}}$ & $48.69 \pm 0.60^{\mathrm{b}}$ \\
Kekuatan gel (nilai) & 2 & - \\
\hline
\end{tabular}

Chirinang dan Intarapichet (2009) menyebutkan Pleurotus memiliki kandungan asam amino arginin, asam aspartat, dan asam glutamat yang tinggi. Begitu pula dengan $V$. volvacea yang memiliki kandungan asam amino polar di antaranya treonin, metionin, lisin, dan histidin (Chang dan Miles, 2004). Adanya komposisi asam amino yang bersifat polar pada $P$. flabellatus dan $V$. volvacea memungkinkan kedua spesies miselium tersebut memiliki kemampuan mengikat air. Asam amino polar memiliki gugus yang dapat berikatan hidrogen dengan air, seperti hidroksil dan karboksil (Adebowale dan Lawal, 2004; Mao dan Hua, 2012). Penelitian mengenai penentuan nilai WHC pada $P$. flabellatus dan $V$. volvacea baru pertama kali dilakukan baik di Indonesia maupun di luar negeri sehingga nilai WHC miselia belum dilaporkan oleh penelitian sebelumnya. Oleh karena itu perbandingan hasil dilakukan terhadap protein nabati lainnya. Nilai WHC kedua sampel lebih rendah daripada pangan nabati sumber protein lain dalam bentuk tepungnya seperti kacang hijau dengan nilai WHC 2.10 g/g atau sekitar 210\% (Dzudie dan Hardy, 1996), kacang merah (Phaseolus lunatus) $2.65 \mathrm{~g} / \mathrm{g}$, dan kacang parang (Canavalia ensiformis) $3.80 \mathrm{~g} / \mathrm{g}$ (Chel-Guerrero et al. 2002). Bentuk tepung dapat menghasilkan nilai WHC lebih tinggi karena keberadaan gugus hidrofilik pada karbohidrat tepung dapat berinteraks dengan air (Adebowale dan Lawal, 2004). Oleh karena itu nilai WHC miselium $P$. flabellatus dan $V$. volvacea dalam bentuk tepung diduga lebih besar dari hasil analisis. Nilai WHC juga dipengaruhi oleh faktor eksternal yang dapat berubah pada saat pengukuran berlangsung seperti pengadukan, kecepatan, $\mathrm{pH}$, dan konsentrasi protein (Chel-Guerrero et al. 2002).

\section{Daya serap minyak/Oil Absorption Capacity (OAC)}

Hasil analisis nilai OAC miselium $V$. volvacea lebih tinggi daripada miselium $P$. flabellatus dengan nilai secara berturutturut ialah 0.80 dan $0.52 \mathrm{~mL} / \mathrm{g}$ (Tabel 1). P. flabellatus dan V. volvacea mengandung asam amino nonpolar seperti valin, leusin, dan isoleusin (Chang dan Miles, 2004; Chirinang dan Intarapichet, 2009). Keberadaan gugus nonpolar pada rantai protein mempengaruhi nilai OAC (Adebowale dan Lawal, 2004). Adanya asam amino nonpolar tersebut memungkinkan kedua miselium yang diuji memiliki kemampuan untuk menyerap minyak. Kehadiran beberapa rantai samping yang bersifat nonpolar dapat berikatan secara hidrofobik (interaksi hidrofobik) dengan rantai hidrokarbon minyak, sehingga semakin banyak komposisi asam amino nonpolar maka daya ikat minyak yang dihasilkan semakin tinggi (Nassar, 2008). Nilai OAC kedua miselium masih lebih rendah dari pada nilai $O A C$ pangan nabati sumber protein lainnya seperti tepung kacang tanah $(1.37 \mathrm{~mL} / \mathrm{g})$ (Adebowale dan Lawal, 2004) dan kacang hijau $2.20 \mathrm{~g}$ minyak/g (Dzudie dan Hardy, 1996). Pembandingan dilakukan terhadap protein nabati lainnya karena belum ada data hasil penelitian terhadap miselium jamur $P$. flabellatus dan $V$. volvacea sebelumnya.

\section{Stabilitas emulsi/emulsion stability}

Nilai stabilitas emulsi pada penelitian ini menunjukkan bahwa miselium $P$. flabellatus memiliki nilai stabilitas emulsi lebih tinggi dibandingkan dengan $V$. volvacea. Nilai stabilitas emulsi miselium $V$. volvacea dan $P$. flabellatus secara berturutturut ialah 48.69 dan $57.14 \%$ (Tabel 1). Nilai stabilitas emulsi kedua sampel dibandingkan dengan konsentrat protein nabati lain sama halnya dengan nilai OAC dan WHC karena belum terdapat penelitian mengenai stabilitas emulsi pada miselium jamur $P$. flabellatus dan $V$. volvacea sebelumnya. Stabilitas emulsi protein sampel uji tergolong rendah jika dibandingkan dengan konsentrat pangan nabati lainnya. Nilai stabilitas emulsi pangan nabati lainnya yang berasal dari konsentrat tepung polong-polongan (buncis dan kacang panjang), serta kacang (kacang bali dan kacang komak) pada pH 6.0 secara berurutan adalah 87.50, 85.71, 85.71, dan 85.71\% (Ahmed et al. 2011). Nilai stabilitas yang rendah pada kedua sampel uji dapat disebabkan diantaranya oleh tingginya kadar air sampel. Data hasil analisis kadar air memperlihatkan bahwa miselium $P$. flabellatus dan $V$. volvacea memiliki kadar air di atas $90 \%$ dan cenderung tidak dipengaruhi oleh waktu pemanenan (Tabel 2).

Tabel 2. Hasil analisis kadar air miselium Pleurotus flabellatus dan Volvariella volvacea

\begin{tabular}{lcc}
\hline \multirow{2}{*}{$\begin{array}{c}\text { Hari Pemanenan } \\
\text { Miselium }\end{array}$} & \multicolumn{2}{c}{ Kadar Air (\%) } \\
\cline { 2 - 3 } Hari ke-7 & Pleurotus flabellatus & Volvariella volvacea \\
Hari ke-8 & $96.60 \pm 0.18^{\mathrm{a}}$ & $94.65 \pm 0.25^{\mathrm{a}}$ \\
Hari ke-9 & $96.67 \pm 0.09^{\mathrm{a}}$ & $94.74 \pm 0.83^{\mathrm{a}}$ \\
\hline
\end{tabular}

Tingginya kadar air pada sampel uji dapat menurunkan kelarutan sampel pada minyak sehingga menghambat aktivitas emulsi dari protein yang dikandungnya. Kelarutan protein merupakan faktor penting dalam sifat pembentukan emulsi (Mao dan Hua, 2012). Selain itu, stabilitas emulsi juga dipengaruhi oleh konsentrasi protein. Konsentrasi protein mempengaruhi kemudahan dalam adsorpsi larutan ke dalam molekul protein (Adebowale dan Lawal, 2004).

\section{Kekuatan ge}

Data hasil analisis pada Tabel 1 menunjukkan bahwa miselium V. volvacea tidak mampu membentuk gel, sedangkan miselium $P$. flabellatus memiliki kualitas gel bernilai 2. Hal ini disebabkan oleh kandungan protein dalam miselium $P$. flabellatus lebih tinggi dibandingkan miselium $V$. volvacea. Eltayeb et al. (2011) menyebutkan bahwa konsentrasi protein merupakan faktor yang mempengaruhi sifat kemampuan pembentukan gel bahan pangan. Hal yang sama disampaikan oleh Dong Sun dan Holley (2011) yang menyebutkan bahwa konsentrasi protein merupakan faktor utama dalam pembentuk- 
an gel yang diinduksi dengan proses pemanasan. Semakin tinggi konsentrasi protein maka semakin kuat dan kaku gel yang terbentuk. Folding test dapat digunakan untuk mengetahul kekuatan gel secara kualitatif. Folding test umumnya dilakukan pada surimi. Surimi memiliki nilai folding test yang tergolong tinggi karena kandungan miofibrilarnya (Hasanpour et al. 2012), sedangkan pada miselium jamur tidak mengandung protein miofibrilar.

\section{KESIMPULAN}

Miselium $P$. flabellatus dan V. volvacea memiliki kandungan protein tertinggi pada pemanenan hari ke-8. Karakteristik fungsional protein menunjukkan nilai WHC $P$. flabellatus dan $V$. volvacea ialah 10.38 dan $15.89 \%$, OAC $P$. flabellatus dan $V$. volvacea ialah 0.52 dan $0.8 \mathrm{~mL} / \mathrm{g}$, nilai stabilitas emulsi $P$. flabellatus ialah $57.14 \%$ dan V. volvacea ialah $48.69 \%$, dan miselium $P$. flabellatus memiliki nilai kekuatan gel 2 , sedangkan miselium V. volvacea tidak dapat membentuk gel. Karakterisitik fungsional protein miselium $P$. flabellatus lebih baik dibandingkan dengan $V$. volvacea ditinjau dari kandungan protein, stabilitas emulsi, dan kemampuan pembentukan gelnya.

\section{UCAPAN TERIMA KASIH}

Penelitian ini dapat terlaksana atas bantuan dana penelitian dari Hibah Penelitian Unggulan Perguruan Tinggi program BOPTN tahun 2013 atas nama Dr.Ir. Soekarno, M.Sc. Dosen pada Departemen IImu dan Teknologi Pangan Fateta IPB, Bogor dengan No. Kontrak: 278/IT3.41.2/L2/ SPK/2013, Direktorat Jenderal Pendidikan Tinggi Kementerian Pendidikan dan Kebudayaan RI.

\section{DAFTAR PUSTAKA}

Adebayo OR, Abidemi OO, Abdulsalam SS. 2013. Functional properties and antinutritional factors of some selected Nigerian cereals. Compr Res J Agr Sci 1: 1-5.

Adebowale KO, Lawal OS. 2004. Comparative study of the functional properties of bambara groundnut (Voandzeia subterranean), jack bean (Canavalia ensiformis), and mucuna beans (Mucuna pruriens) flours. Food Res Int 37: 355-364. DOI: 10.1016/j.foodres.2004.01.009.

Ahmed SH, Ahmed IAM, Eltayeb MM, Ahmed SO, Babiker EE. 2011. Functional properties of selected legumes flours as influenced by pH. J Agr Technol 7: 1291-1302.

Aminuddin $\mathrm{H}$, Khan AM, Abidin H, Madzlan K, Suri R, Kamal MK. 2007. Optimization of submerged culture for the production of Lentinula edodes mycelia biomass and amino acid composition by different temperature. J Trop Agr Food Sci 35: 131-138.

[AOAC] Association of Official Agricultural Chemist. 1995. Official Methods of Analysis of The Association of Official Agricultural Chemist. AOAC, Inc., Washington.
Asgar MA, Fazilah A, Huda N, Bhat R, Karim AA. 2010. Nonmeat protein alternatives as meat extenders and meat analogs. Compr Rev Food Sci F 9: 513-529. DOI: 10.1111/j. 1541-4337.2010.00124.X.

Chang ST, Miles PG. 2004. Mushrooms: Cultivation, Nutritional Value, Medicinal Effect, and Environmental Impact. CRC Press, Boca Raton.

Chel-Guerrero L, Perez-Flores V, Bentacur-Ancona D, DavilaOrtiz G. 2002. Functional properties of flours and protein isolates from Phaseolus lunatus and Canavalia ensiformis seeds. J Agr Food Chem 50: 584-591. DOI: 10.1021/ jf010778j.

Chirinang P, Intarapichet KO. 2009. Amino acids and antioxidant properties of the oyster mushrooms, Pleurotus ostreatus and Pleurotus sajor-caju. Sci Asia 35: 326-331. DOI: 10.2306/scienceasia1512-1874.2009.35. 326.

Deng $Q$, Wang L, Wei F, Xie B, Huang FH, Huang W, Shi J, Huang Q, Tian B, Xue S. 2011. Functional properties of protein isolates, globulin, and albumin extracted from Ginkgo biloba seeds. Food Chem 124: 1458-1465. DOI: 10.1016/j.foodchem.2010.07.108.

Dong Sun X, Holley RA. 2011. Factors influencing gel formation by myofibrillar protein in muscle foods. Compr Rev Food Sci F 10: 33-51. DOI: 10.1111/j.1541-4337.2010.00137.x.

Dzudie T, Hardy J. 1996. Physicochemical and functional properties of flours prepared from common beans and Green Mung beans. J Agr Food Chem 44: 3029-3032. DOI: 10.1021/jf9504632.

Eltayeb ARSM, Ali AO, Abou-Arab AA, Abu-Salem FM. 2011. Chemical composition and functional properties of flour and protein isolate extracted from Bambara groundnut (Vigna subterranean). Afr J Food Sci 5: 82-90.

Fekria AM, Isam AMA, Suha OA, Elfadil EB. 2012. Nutritional and functional characterization of defatted seed cake flour of two Sudanese groundnut (Arachis hypogaea) cultivars. Int Food Res J 19: 629-637

Hasanpour F, Hoseini E, Motalebi AA, Darvish F. 2012. Effects of soy protein concentrate and xanthan gum on physical properties of Silver carp (Hypophthalmichthys molitrix) surimi. Iran J Fish Sci 11: 518-530.

Hung PV, Nhi NNY. 2012. Nutritional composition and antioxidant capacity of several edible mushrooms grown in the Southern Vietnam. Int Food Res J 19: 611-615.

Hosseini SM, Khosravi-Darani K. 2010. Response surface methodology for mycoprotein production by Fusarium venenatum ATCC 20334. J Bioprocess Biotechniq 1: 1-5. DOI: 10.4172/2155-9821.1000102.

Kalac P. 2012. Chemical Composition and Nutritional Value of European Species of Wild Growing Mushrooms. In: Andres S, Baumann N. (eds). Mushrooms: Types, Properties, and Nutrition. 130-152. Nova Science Publishers, Inc, Hauppauge, New York.

Lakshmi SS. 2013. Comparative study on mycelia growth rate of Ganoderma Lucidum and Pleurotus flabellatus on agrowastes. Int J Advance Res 1: 199-203. 
Lin MY, Humbert GS, Sosulski FW. 1974. Certain functional properties of sunflower meal products. J Food Sci 39: 368370. DOI: 10.1111/j.1365-2621.1974.tb02896.x.

Mao X, Hua Y. 2012. Composition, structure, and functional properties of protein concentrates and isolates produced from walnut (Juglans regia L.). Int J Mol Sci 13: 1561-1581. DOI: $10.3390 /$ ijms13021561.

Mshandete AM, Mgonja J. 2009. Submerged liquid fermentation of some Tanzanian basidiomycetes for the production of mycelia biomass, exopolysaccharides and mycelium protein using wastes peels media. J Agric Bio Sci 4: 1-13.

Nassar AG. 2008. Chemical composition and functional properties of prickly pear (Opuntia ficus indica) seeds flour and protein concentrate. World J Dairy Food Sci 3: 11-16.

Reis FS, Barros L, Martins A, Ferreira ICFR. 2012. Chemical composition and nutritional value of the most widely appreciated cultivated mushrooms: an inter-species comparative study. Food Chem Toxicol 50: 191-197. DOI: 10.1016/j.fct.2011.10.056.

Richi R. 2011. Kajian Terhadap Jamur Pangan Pelawan (Boletus sp.) Khas Indonesia sebagai Sumber Potensial Pangan Fungsional [Skripsi]. Bogor: Fakultas Teknologi Pertanian, Institut Pertanian Bogor.
Srivastava HC, Bano Z. 1970. Nutrition requirement of Pleurotus flabellatus. Appl Microbiol 19: 166-169

Suzuki T. 1981. Fish and Krill Protein Processing Technology. Applied Science Publisher Ltd. Tokyo, Japan.

Wroldstad RE, Decker EA, Schwartz SJ, Sporns P. 2005. Handbook of Food Analitycal Chemistry. John Willey and Sons Inc. New Jersey.

Wong KH, Aziz SA, Mohamed S. 2008. Sensory aroma from Maillard reaction of individual and combinations of amino acids with glucose in acidic conditions. Int J Food Sci Technol 43: 1512-1519. DOI: 10.1111/j.1365-2621.2006. 01445.x.

Wu H, Wang Q, Ma T, Ren J. 2009. Comparative studies on the functional properties of various protein concentrate preparations of peanut protein. Food Res Int 42: 343-348. DOI: 10.1016/j.foodres.2008.12.006.

Xie YR, Hettiarachchy NS. 1997. Xanthan gum effects on solubility and emulsification properties of soy protein isolate. J Food Sci 62: 1001-1003. DOI: 10.1111/j.1365-2621. 1997.tb12222.x. 